\title{
Experience and perspectives of cross-breeding in milk cattle husbandry
}

M. Bashchenko,

Academician of the NAAS, doctor of agricultural sciences

A. Kostenko, candidate of agricultural sciences

National Academy of Agrarian Sciences of Ukraine

S. Ruban,

Corresponding Member of the National Academy of Sciences of Ukraine, Doctor of Agricultural Sciences

Institute of Animal Breeding and Genetics of the NAAN named after MV Tooth

The purpose. On the basis of world experience to show the role of cross-breeding for justification of mercantilely attractive alternatives of crossing in programs of selection of domestic dairy breeds of cattle. Methods. Historical method, use of analytically compared empirical data gained by experimenters worldwide concerning effect of crossing dairy breeds. Results. Recommendations are diven for further improvement by selection method owing to use of crosses of domestic breeds (Ukrainian red-motley and Ukrainian blackmotley milk). Conclusions. Rigid market conditions demand quick search and justification of more efficient programs of selection in cattle husbandry. The availability of crossing genetic differences at dairy breeds, their mating allows to gain genetic improvement of economically important selection tags, development of economically important productive tags of animals of Golshtin breed using method of mating with "contrasting" breeds. The main effect at mating Golshtin breed with series of European breeds is observed to tags of reconstituting and survival rate of calves. One of directions of such development of domestic dairy breeds is searching optimum alternatives of their mating with the following breeds: Monbelyard, Red Swedish, Red Scandinavian, Shvits, and Jersei.

Key words: cross-breeding, dairy breeds of cattle, selection, mating, reconstituting, productive longevity.

Methods of pure breeding or crossing are constantly used at the programs of improving of cattle dairy breeds of different countries (S.Yu. Ruban, 1985; M.V. Zubets, Yu.M. Karasyk, V.P. Burkat et al., 1990; Yu.F. Melnyck, V.P. Burkat, M.I. Bashchenko et al., 2003; V.P. Burkat, M.Ya. Yefimenko, 2003, P.M. VanRaden, A.H. Sanders, 2003; B. Cassel, Y. Allister, 2009; B. Heins, L. Hansen, F. Seykora, 2007.).

Considering breed as open and dynamic system, one can quote citation, made by outstanding Ukrainian scientists at the end of 90-ies of last century and which is actual: «lt is unacceptable to ignore the experience of specialists of Great Britain, Netherlands, Germany, Switzerland, which threw away patriarchal ambitions and in the most wide way use the best gene pool of dairy breeds from the North America» (M.V. Zubets, V.P. Burkat, 1997). Time is fast flowing and already practical breeders of the North America countries use material of such European countries as Germany, Austria, Swiss, Finland and so on.

Evaluating peculiarities of scientific and industrial cooperation structure at post-soviet space and abroad (Azbel M., 1991) one can conclude, that mobility, and the speed of response to severe market society challenges - the main condition of scientific survival. 
Ukrainian Red-and-White Dairy breed - the first breed, which became a result of continued creative scientific and practical work of animal-breeding branch specialists (Yu.F. Melnik, V.P. Burkat, M.I. Bashchenko et al., 2003).

The breed was tested and officially approved as the first native specialized dairy with the Scientific-technical council of the Ministry of Agriculture and Food of Ukraine in 1992. The breed is created, using the method of reproductive crossing of Simmental breed (maternal base) with Red Holstein (USA, Canada), and (south-eastern innerbreed type) as paternal breeds were used sires of Montbeliard (France) and Ayrshire (Finland) breeds.

Grounding the schemes of improving of double directed Simmental breed as improving were chosen Montbeliard, Ayrshire, Red Holsten (M.V. Zubets, Yu.M. Karasyk, V.P. Burkat et al., 1990). Ukrainian Black-and White Dairy breed was recognized as selection achievement in 1995 and approved with the order of the Minister of Agriculture and Food of Ukraine on April, 26 of 1996 under № 127. The total number of this breed cows was $1,7 \mathrm{mln}$, and a share over all farms $-35 \%$. Only in base (breeding) farms productivity of 6176 heifers was $5558 \mathrm{~kg}$ of milk with fat content 3,86 \% (V.P. Burkat, M.Ya. Yefimenko, 2003).

Maternal base of breed became Simmental and Holland breeds, and preferably pure Holstein sires. Genotype of these animals contained $62,5-75 \%$ and more heredity of improving Holstein breed. For the last years in Ukraine there is tendency to cows number increasing in controlled (breeding) part, which accounts for the last years within 129 th. of cows, where Holsteins $-13 \%$ of total number (Table 1). Sharp increasing of Swiss breed number is caused by strong dairy complex "Yekaterinoslavskiy» creation in Dnipropetrovsk region, where near 800 heifers were imported from abroad.

Certain effect of crossing with Holstein by yield during native dairy breeds creation and dumping at the market of sperm production deliveries resulted in absorbing crossing and along with it display of certain problems of new-created native breeds, which were linked with lowering of reproductive ability, productive longevity, product quality. This problem can be illustrated as well by change of selection evaluative strategies of Holstein breed first-hand in USA.

\section{Cows number of different dairy breeds in dairy cattle breeding of Ukraine for the number} of years.

\begin{tabular}{|l|l|l|}
\hline \multirow{2}{*}{ Breed } & Number of cows, ones \\
\cline { 2 - 3 } & $\mathbf{2 0 1 3}$ & $\mathbf{2 0 1 4}$ \\
\hline Ukrainian Black-and-White Dairy & 62690 & 69328 \\
\hline Ukrainian Red-and-White Dairy & 26395 & 27672 \\
\hline Holstein & 11928 & 16286 \\
\hline Ukrainian Red Dairy & 6665 & 6334 \\
\hline Simmental & 2230 & 3623 \\
\hline Red Polish & 506 & 294 \\
\hline Red Steppe & 3244 & 2291 \\
\hline Ayrshire & 539 & 513 \\
\hline Angler & 39 & 248 \\
\hline Lebedyn & 947 & 713 \\
\hline Swiss & 100 & 1085 \\
\hline Ukrainian Brown Dairy & 350 & 350 \\
\hline Whiteheaded Ukrainian & 300 & 300 \\
\hline Total & $\mathbf{1 1 5 9 3 3}$ & $\mathbf{1 2 9 0 3 7}$ \\
\hline
\end{tabular}

So, analysis of priorities evolution concerning selection directions of USA Holstein cattle during 1971-2014 demonstrates, that there is happened not only number of sire selection traits in- 
creasing, but as well economically significant matching priorities changing (Table 2). For example, in 1971 evaluation index consisted of $52 \%$ yield value and $48 \%$ milk fat, and now economic value on yield is negative. At the same time significantly increased economic weight of such fitness traits as productive longevity, somatic cell score, type, reproductive traits (Table 2).

2. Change of relative economic weight (\%) of selection traits in Holstein cattle breeding value evaluation indices (P.M. VanRaden, J. B. Cole, 2014)

\begin{tabular}{|c|c|c|c|c|c|c|c|}
\hline \multirow[b]{2}{*}{ Traits } & \multicolumn{7}{|c|}{ Index and year of its introduction } \\
\hline & $\begin{array}{l}\text { PD\$ } \\
\text { (1971) }\end{array}$ & $\begin{array}{l}\text { NM\$ } \\
\text { (1994) }\end{array}$ & $\begin{array}{l}\text { NM\$ } \\
(2000)\end{array}$ & $\begin{array}{l}\text { NM\$ } \\
(2003)\end{array}$ & $\begin{array}{l}\text { NM\$ } \\
(2006)\end{array}$ & $\begin{array}{l}\text { NM\$ } \\
(2010)\end{array}$ & $\begin{array}{l}\text { NM\$ } \\
(2014)\end{array}$ \\
\hline Yield & 52 & 6 & 5 & 0 & 0 & 0 & -1 \\
\hline Milk fat & 48 & 25 & 21 & 22 & 23 & 19 & 22 \\
\hline Milk protein & & 43 & 36 & 33 & 23 & 16 & 20 \\
\hline Productive longevity & & 20 & 14 & 11 & 17 & 22 & 19 \\
\hline Somatic cell score & & -6 & -9 & -9 & -9 & -10 & -7 \\
\hline Summarized udder score & & & 7 & 7 & 6 & 7 & 8 \\
\hline Summarized limbs score & & & 4 & 4 & 3 & 4 & 3 \\
\hline Summarized score on body size & & & & -3 & -4 & & -5 \\
\hline Daughters' level of fertility & & & & 7 & 9 & 11 & 7 \\
\hline Cows' level of fertility & & & & & & & 2 \\
\hline Heifers' fertility level & & & & & & & 1 \\
\hline Calving ability & & & & & 6 & 5 & 5 \\
\hline
\end{tabular}

Notes: PD\$ - predicted difference, dollars

NM\$ - net merit, dollars

However, existing certain differences in breeding value evaluation systems of different countries couldn't but make genetic difference between breeds.

Analysis of production traits of major commercial dairy breeds in data of International Committee on Animal Records (ICAR) allow to find ones, which differs significantly on the level of development of main traits from popular in the world Holstein breed (Table 3).

3. Production of cows of main breeds at certain countries on data of breeding records in 2013 (www.icar.org/wp - content/uploads/2015/08/cow survey Publication 2012-2013.)

\begin{tabular}{|c|c|c|c|c|c|c|c|}
\hline \multirow{2}{*}{$\begin{array}{l}\text { № } \\
\text { /n }\end{array}$} & \multirow[b]{2}{*}{ Country } & \multirow[b]{2}{*}{ Breed } & \multirow{2}{*}{$\begin{array}{l}\text { Number of } \\
\text { lactations }\end{array}$} & \multirow{2}{*}{$\begin{array}{l}\text { Milk produc- } \\
\text { tion for } 305 \\
\text { days }\end{array}$} & \multicolumn{2}{|c|}{ Percent,\% } & \multirow{2}{*}{$\begin{array}{l}\text { Calving } \\
\text { interval }\end{array}$} \\
\hline & & & & & fat & $\begin{array}{l}\text { pro- } \\
\text { tein }\end{array}$ & \\
\hline \multirow{4}{*}{1} & \multirow{4}{*}{ USA } & Holstein & 3709885 & 10967 & 3,70 & 3,08 & - \\
\hline & & Jersey & 252822 & 7941 & 4,82 & 3,65 & - \\
\hline & & Swiss & 11249 & 8590 & 4,19 & 3,42 & - \\
\hline & & Ayrshire & 4250 & 6877 & 3,92 & 3,17 & - \\
\hline \multirow{4}{*}{2} & \multirow{4}{*}{ Canada } & Ayrshire & 8499 & 7659 & 4,05 & 3,36 & - \\
\hline & & Swiss & 1877 & 8254 & 4,13 & 3,51 & - \\
\hline & & Holstein & 288717 & 9979 & 3,8 & 3,19 & - \\
\hline & & Jersey & 10726 & 6607 & 4,91 & 3,79 & - \\
\hline \multirow{3}{*}{3} & \multirow{3}{*}{ Austria } & Holstein & 36934 & 8483 & 4,09 & 3,27 & - \\
\hline & & Simmental & 249030 & 7103 & 4,15 & 3,41 & - \\
\hline & & Swiss & 42647 & 7111 & 4,16 & 3,45 & - \\
\hline
\end{tabular}




\begin{tabular}{|c|c|c|c|c|c|c|c|}
\hline \multirow{2}{*}{4} & \multirow{2}{*}{ Denmark } & Holstein & 363282 & 9661 & 4,09 & 3,38 & - \\
\hline & & Red Danish & 34697 & 8820 & 4,30 & 3,51 & - \\
\hline \multirow{3}{*}{5} & \multirow{3}{*}{ France } & Montbeliard & 421130 & 7023 & 3,86 & 3,41 & 399 \\
\hline & & Norman & 225713 & 6524 & 4,19 & 3,58 & 404 \\
\hline & & Prime Holstein & 1681336 & 8995 & 3,87 & 3,28 & 430 \\
\hline \multirow{3}{*}{6} & \multirow{3}{*}{ Finland } & Ayrshire & 135381 & 8731 & 4,27 & 3,41 & 418 \\
\hline & & Holstein & 80231 & 9574 & 3,96 & 3,29 & 418 \\
\hline & & Jersey & 237 & 7522 & 4,74 & 3,58 & 406 \\
\hline \multirow{2}{*}{7} & \multirow{2}{*}{ Norway } & Norvegian Red (NRF) & 138715 & 7074 & 4,20 & 3,38 & 380 \\
\hline & & Holstein & 1227 & 8775 & 4,08 & 3,32 & 395 \\
\hline \multirow{2}{*}{8} & \multirow{2}{*}{ Sweden } & Swedish Red $^{*}$ & 116573 & 8753- & 4,36 & 3,56 & 398 \\
\hline & & Holstein & 147924 & 9764 & 4,10 & 3,38 & 413 \\
\hline \multirow{4}{*}{9} & \multirow{4}{*}{ Germany } & Swiss & 167609 & 6998 & 4,24 & 3,58 & 415 \\
\hline & & Simmental & 890211 & 7069 & 4,16 & 3,50 & 393 \\
\hline & & $\begin{array}{l}\text { Holstein Black-and- } \\
\text { White }\end{array}$ & 2123027 & 8791 & 4,07 & 3,37 & 415 \\
\hline & & $\begin{array}{l}\text { Holstein Red-and- } \\
\text { White }\end{array}$ & 241082 & 7859 & 4,23 & 3,40 & 411 \\
\hline
\end{tabular}

'2012 years' data.

In our opinion, such breeds are the groups of «local" breeds of such countries as Sweden, Norway, Finland, France, Austria, Germany. It's the innerbreed genetic differences, that made breeders to improve economically important productive traits of Holstein breed by crossing it with "contrast" breeds.

So, in the early 2000-s specialists of Animal Improvement Program Laboratory, strategic developments of which are funded by Ministry of Agriculture of USA, a work on different breed combinations evaluation amongst dairy breeds of USA was done (Table 4).

4. Average value of different indices of evaluation of crosses of first generation $\left(F_{1}\right)$ compared to pure bred Holsteins (P.M. Van Raden, A.H. Sanders, 2003)

\begin{tabular}{|c|c|c|c|}
\hline $\begin{array}{l}\text { Combination of parental } \\
\text { breeds }\end{array}$ & $\begin{array}{l}\text { Total value } \\
(\$)^{*}\end{array}$ & $\begin{array}{l}\text { Value for pro- } \\
\text { cessing of milk into } \\
\text { cheese } \\
(\$)^{*}\end{array}$ & Milk value \\
\hline Ayrshire & -58 & -27 & -201 \\
\hline Swiss & 18 & 79 & -241 \\
\hline Guernsey & -184 & -138 & -395 \\
\hline Jersey & 44 & 113 & -269 \\
\hline Dairy Shorthorn & -249 & -223 & -373 \\
\hline
\end{tabular}

- ratio in dollar equivalent

Analysis involved 41131 crossbred and 726344 purebred Holstein cows, which lactated from 1960 till 1991. According to P.M. Van Raden, A.H. Sanders (2003) total effect of heterosis when crossing of Holstein cows with bulls of Ayrshire, Swiss, Jersey, Guernsey and Dairy Shorthorn breed was in yield $3,4 \%$, fat content $-4,4 \%$, protein content $-4,1 \%$, at the same time gene recombination effect (creation of new detached DNA areas in genome after crossing) fluctuated on mentioned productive traits from 2,2 till 1,9\%. Summing up such crossing in general, genetic effect was estimated in dollar equivalent (Table 4). On traits of absolute dairy production Holsteins 
were the first (all crosses yielded to this breed), but on traits, connected with milk quality or total value (Net merit) crosses with Swiss and Jersey breeds were leading (Table 4).

To a certain extent it stimulated the development as Swiss and Jersey breeds in USA, so the popularity of their crossing with Holstein cows. These trends were widely picked up by the service of scientific developments implementations (Extension) into practice in USA.

According to B.Cassel, J.Allister (2009), large part of such work was done by cooperatives on implementations of Virginia state.

Farmers significantly noted certain effect on the results of crossing on such traits as milk quality and reproduction level (Table 5).

\section{Results of crossing of Holsteins and European improving breeds}

\begin{tabular}{|c|c|c|c|c|}
\hline \multirow[b]{2}{*}{ Traits } & \multirow[b]{2}{*}{ Holsteins } & \multicolumn{3}{|c|}{ Crossing combinations } \\
\hline & & $\begin{array}{ll}\text { Holsteins } & X \\
\text { Normans } & \end{array}$ & $\begin{array}{l}\text { Holsteins } \quad x \\
\text { Montbeliards }\end{array}$ & $\begin{array}{l}\text { Holstein x Scan- } \\
\text { dinavian Red }\end{array}$ \\
\hline $\begin{array}{l}\text { Number of } \\
\text { animals }\end{array}$ & 380 & 245 & 494 & 327 \\
\hline Yield, kg & 9766 & 8537 & 9169 & 9289 \\
\hline Fat content, \% & 3,55 & 3,76 & 3,65 & 3,66 \\
\hline $\begin{array}{l}\text { Protein content, } \\
\%\end{array}$ & 3,13 & 3,25 & 3,20 & 3,20 \\
\hline Distocia, \% & 17,70 & 11,60 & 7,20 & 3,70 \\
\hline Stillbirth, \% & 14,00 & 9,90 & 6,20 & 5,10 \\
\hline
\end{tabular}

Great experience in American Holstein breed crossing with sires of such European breeds as Montbeliard (France), Scansinavian Red (Sweden), Norman (France), Swiss (Austria, Germany) is cumulated in Virginia state. In Table 6 there are given the results of 2- and 3-breed crossing combinations (B. Heins, L. Hansen, F. Seykora, 2007), which were hold at some farms of USA.

Given data witness about some advantages on milk protein and fat yield of 3-breed crosses, compared to 2-breed ones. According to these authors when using 3-breed combination schemes one can see maximum heterosis effect, but after this one should orient the system of sire matching again to the main breed, in this case - Holstein.

6. Production of heifers of different genetic combinations for $\mathbf{3 0 5}$ days of the first lactation

\begin{tabular}{|c|c|c|c|c|c|}
\hline \multirow{2}{*}{ Crosses } & \multirow{2}{*}{$\begin{array}{l}\text { Cows, } \\
\text { ones }\end{array}$} & \multirow{2}{*}{$\begin{array}{l}\text { Number of } \\
\text { cows' fa- } \\
\text { thers, ones }\end{array}$} & \multirow{2}{*}{ Yield, kg } & \multicolumn{2}{|c|}{ Yield of milk } \\
\hline & & & & fat & protein \\
\hline \multicolumn{6}{|l|}{ 2-breed } \\
\hline Holstein x Norman & 37 & 9 & 8865 & 345 & 288 \\
\hline Holstein x Montbeliard & 366 & 32 & 9432 & 351 & 302 \\
\hline Holstein $\times$ Scandinavian Red & 162 & 15 & 9500 & 350 & 305 \\
\hline \multicolumn{6}{|l|}{ 3-breed } \\
\hline Holstein x Swiss x Montbeliard & 44 & 8 & 9297 & 349 & 302 \\
\hline $\begin{array}{l}\text { Red Holstein x Montbeliard x Scandina- } \\
\text { vian }\end{array}$ & 43 & 9 & 9461 & 356 & 308 \\
\hline $\begin{array}{l}\text { Holstein x Scandinavian Red x Norman x } \\
\text { Montbeliard }\end{array}$ & 86 & 10 & 8809 & 361 & 320 \\
\hline
\end{tabular}


According to B.Y. Heins., L,B. Hansen., A.Y. Seykora (2006), the main effect when crossing Holstein breed with European breeds is found for reproduction and calves' survival traits (Table 7).

7. Distocia and stillbirth cases of purebred Holsteins and crosses

\begin{tabular}{|l|l|l|l|}
\hline Breed, crosses & № & Distocia, \% & Stillbirth, \% \\
\hline Purebred Holsteins & 676 & 17,7 & 14,0 \\
\hline Holstein x Normans & 262 & 11,6 & 9,9 \\
\hline Holstein x Montbeliard & 370 & 7,2 & 6,2 \\
\hline Holstein x Scandinavian Red & 264 & 3,7 & 5,1 \\
\hline
\end{tabular}

From economical point of view prevailing of these traits is very important for their more profitable position.

Taking into account native and foreign experience, one can recommend for the improving of Ukrainian Red-and-White and Black-and-White Dairy breeds as improving breeds, which are mentioned in Table 8.

8. Breeds, recommended for the realization pf program «Procross» at the cows of native Red-and-White and Black-and-White dairy breeds of Ukraine

\begin{tabular}{|l|l|}
\hline Breeds, which should be improved & $\begin{array}{l}\text { Improving breeds } \\
\text { (country of origin) }\end{array}$ \\
\hline \multirow{3}{*}{ Ukrainian Red-and-White dairy } & $\begin{array}{l}\text { Montbeliard (France) } \\
\text { Red Swedish (Sweden) } \\
\text { Ayrshire (Finland) }\end{array}$ \\
\hline \multirow{3}{*}{ Ukrainian Black-and-White dairy } & $\begin{array}{l}\text { Red Swedish (Sweden) } \\
\text { Swiss (Austria, Germany) } \\
\text { Jersey (USA) }\end{array}$ \\
\hline
\end{tabular}

Methodology of evaluation as the results of innerbreed crossing, so heterosis effect display was repeatedly highlighted in the works of certain scientists (S.Yu. Ruban, 1999; S.Yu. Ruban, V.A. Dunshyn, 2002; V.A. Danshyn, 2008; G.E. Dickerson, 1973; E.U. Dillard, O. Rodriguez, O.W. Robison, 1980; O.W. Robison, B.T. McDaniel, E.J. Rincon, 1981). Such approaches are widely recognized and often used for the reliable estimation of genetic and non-genetic factors impact.

So, availability of several breeds or crosses in a population of estimated animals gives certain peculiarities into evaluation of breeding value (V.A. Dunshyn, 2008). Such peculiarities are:

1. Necessity of strict breed composition record or formal counting of blood share of different breeds inside crosses' genetic composition, when define genetic groups.

2. Availability of innerallele effects of breed genes interaction (heterosis), when interallele effects are considered by way of including into linear model of effect of different breed effects.

Methodics of evaluation of general genetic value with including of heterosis effect $\left(G_{1}\right)$ looks as follows (V.A. Danshyn, 2008):

$\mathrm{G}_{\mathrm{l}}=\mathrm{u}_{\mathrm{i}}+\Sigma_{\mathrm{l}} \mathrm{S}_{\mathrm{i}} \mathrm{h}_{\mathrm{l}}$

where $S_{i}$ - predicted part of loci in the genotype of $i$-th animal, heterosis breeds of the l-st combination; $h_{1}$ - heterosis effect for the l-st breed combination; $u_{i}$ - additive genetic (breeding) value of $i$-th animal.

As addition to this proposal can be treated recommendations on careful analysis of proposed crossing schemes when realizing at the base of breeding, zootechnical, and especially, genetic control in farms of Ukraine. 


\section{Conclusions}

Availability of innerbreed genetic features on fitness and productive traits between Holstein breed and breeds of European selection allows at their crossing to get genetic improving of economically important selection traits. The main effect in this case is found on reproductive and calves' survival traits. One of the directions of such improving of native dairy breeds is a search of optimum ways of crossing of them with such breeds as Montbeliard, Red Swedish, Red Scandinavian, Swiss and Jersey.

\section{Bibliography}

1. Azbel Mark. Yerusalymskye razmushlenyya // Pryroda, \#10, 1991, S. 82 - 90.

2. Zubets M.V., Burkat V.P. Do pytannya pro porodoutvoryuval'ni protsesy $v$ molochnomu skotarstvi Ukrayiny. Visnyk ahrarnoyi nauky. 1997, \# 2, s.

3. Mel'nyk Yu.F., Burkat V.P., Bashchenko M.I. ta inshi. Prohrama selektsiyi ukrayins'koyi chervo-no-ryaboyi molochnoyi porody velykoyi rohatoyi khudoby na 2003-2012 roky. DNVK «Selektsiya», K., 2003, 76 s.

4. Zubets M.V., Karasyk Yu.M., Burkat V.P. y dr. Preobrazovanye henofonda porod. Pod red. M.V. Zubtsa. - K.: Urozhay, 1990. - 352 s.

5. Prohrama selektsiyi ukrayins'koyi chorno-ryaboyi molochnoyi porody velykoyi rohatoyi khudoby na 2003-2012 roky. Pid zahal'noyu redaktsiyeyu V.P. Burkata, M.Ya. Yefimenka, DNVK «Selektsiya», 2003, $84 \mathrm{~s}$.

6. Danshyn V.A. Otsenka henetycheskoy tsennosty zhyvotnыkh. - K.: Ahrarna nauka, 2008. $180 \mathrm{~s}$.

7. Ruban S.Yu., Danshyn V.A. Otsenka эffektyvnosty mezhporodnoho skreshchyvanyya v moloch-nom skotovodstve. //Problemy zooinzheneriyi ta veterynarnoyi medytsyny (zbirnyk naukovykh prats'). Vyp. 11 (35). Chastyna 1. Sil's'kohospodars'ki nauky. 2002, Kharkiv, S.130-136.

8. Ruban S.Yu. Efektyvnost' skreshchyvanyya pry sozdanyy novoho molochnoho typa v symmen-tal'skoy porode. Dokladы VASKhNYL, 1985, \# 6, S. 46-47.

9. Ruban S.Yu. Ukrayins'ka chervono-ryaba molochna. Novi metody stvorennya y udoskonalennya porody. Tvarynnytstvo Ukrayiny, 1996, \# 10, S. 10-12.

10. Van Raden P.M., Sanders A.H.. Economic Merit of Crossbred and Purebred US Dairy Cattle. Yournal of Dairy Science 2003 \# 86, R 1036-1044.

11. Dickerson G.E. Inbreeding and heterosis in animals. //Proc. Anim. Breed. Genet. Symp. in Honor of Dr.J.L.Lush. Am. Soc. Anim. Sci. and Am. Dairy Sci. Assoc. Champaign, 1973, 54 r.

12. rDillard E.U., Rodriguez O., Robison O.W. Estimation of additive and non-additive direct and maternal genetic effects from crossbreeding beef cattle. //J.Anim. Sci., 1980, V.50, 653 p.

13. Robison O.W., McDaniel B.T., Rincon E.J. Estimation of direct and maternal additive and heterotic effects from crossbreeding experiments in animals. //J.Anim. Sci., 1981, V.52, 44 p.

14. Cassel Bennet, Allister Yack. Dairy Crossbreeding Research. Publication 404-094, Virginia Cooperative Extension, 2009, 6 p.. (www.ext.vt.edu).

15. Heins B., Hansen L., Seykora F. The California experience of mating Holstein cows to A.I. sires from the Shedis Red, Norwegin Red, Monbeliarde and Normande breeds (Updated results of crossbreeding of dairy cattle. Jule 2007). Uniresity of Minnesota department of animal science, dairy cattle research: crossbreeding of dairy cattle.

16. Heins B., Hansen L., Seykora F. Calving difficulty and stillbirth of pure Holstein versus crossbreds of Holstein with Normande, Monbeliarde and Scandinavian red. Yornal of Dairy Sciens, 2006, \# 89, R. 2805-2810.

17. Van Raden P.M., Cole J.B. Net merit as a measure of lifetime profit: 2014 revision // Animal improvement Program, Animal Genomics and improvement laboratory, Agricultural Research Ser-vice, USDA, Beltsville. MD., 2014. 